\title{
Ethics, Corporations, and Governance
}

\author{
Wesley Cragg $\cdot$ Dirk Matten
}

Published online: 21 February 2012

(C) Springer Science+Business Media B.V. 2012

\begin{abstract}
Corporate governance has resurfaced as a topic in the ongoing financial crises. This article frames the debate on corporate governance within the ongoing concerns about the corporate role in wider societal governance. It then maps out the context of the six scholarly contributions in this special issue by highlighting how the current debate moves towards a closer integration of governance at corporate and societal level.
\end{abstract}

Keywords Corporate governance - Governance ·

Shareholder value · Financial crisis · Occupy Wall Street

Ever since Berle and Means (1932) published their seminal piece on corporate governance in the early 1930s, the thorny question of how to run a business in the interest of those who are affected by its performance has occupied the minds of business practitioners and scholars alike. Berle and Means, just to refer to some of the main paradigmatic voices in the debate, offered their then new diagnosis of corporate governance, a diagnosis which could in many ways be considered still applicable.

In 1929, the world economy collapsed in what could be considered the first incident of the then fairly young experiment of making capitalism and democracy work

\footnotetext{
W. Cragg $(\bowtie)$

Canadian Business Ethics Research Network (CBERN),

Schulich School of Business, York University, 4700 Keele

Street, Toronto M3J 1P3, Canada

e-mail:wcragg@schulich.yorku.ca

D. Matten

Schulich School of Business, York University, 4700 Keele

Street, Toronto M3J 1P3, Canada

e-mail: dmatten@schulich.yorku.ca
}

simultaneously. It appears that today we have reached these crossroads again. The rise of the modern corporation was a huge success initially. Not only did it provide the institutional backdrop and mechanisms for much of the industrial revolution, ultimately allowing for new ways of combining production factors, most notably labor and capital (in all its forms). The modern corporation, with its characteristic split between ownership and control, also paved the way for major innovations in infrastructure, most notably the spread of railways in the UK and then subsequently in North America (Bakan 2004).

By the early twentieth century, though, it had also become more than obvious that this new system of capitalistic wealth creation, in which the modern corporation had emerged to become a pivotal player, was grappling with two inherent problems (Crouch 2009). First, the capitalist system had produced rather stark inequalities in the distribution of wealth in many of the societies within which it so successfully had spread. Second, the capitalist system, left to a laisser-faire approach of public economic policies, was subject to cyclical ups and downs to which labor was particularly exposed and vulnerable.

By the mid twentieth century, after the painful experience of depression and the rise of anti-democratic, totalitarian ideologies on the left and on the right in Europe, the solution to these governance challenges were found in a new governmental role for steering national economies. Welfare state institutions addressed the more extreme forms of inequality while governments in post-war economies actively intervened to manage economic cycles (often referred to as "Keynesianism"). The result was an approach to government and economic management that seemed compatible with basic democratic and economic values and principles.

Conspicuously, these public governance mechanisms did not initially question the way private corporations were 
run. They touched on the way the economic results were distributed, but did not challenge the basic economic interests which private business was supposed to serve. Even the changes often deemed as "neo-liberalism," visible in many economies after the 1980s, did not change underlying governance functions fundamentally. Rather policy initiatives under Ronald Reagan in the United States and Margaret Thatcher in the United Kingdom mainly changed the role and degree of responsibility of individual citizens in these societies, by increasing home ownership and initiating a shift from welfare-based to investmentbased entitlement programs ("privatized Keynesianism," as Colin Crouch (2009)has referred to it).

The latter approach, however, has today come to a grinding halt as a result of the financial crises of the first decade of the current century. Today, the debate on inequality and addressing a recession has clearly a new dimension which transcends the debates on the role of government in economic management that dominated the twentieth century. The strength of the "Occupy Wall Street" movement suggests questions about in whose interests shareholder-owned financial institutions (and for that matter: most private businesses) are run, has moved to the core of political and economic debates in most industrialized countries.

These developments have put corporate governance back on the public agenda where increasingly they are being seen as linked to questions of wider societal governance. If banks and other companies are so important that they are deemed "too big to fail" and must be rescued by the injection of large amounts of public financial resources-in whose interest should they be run? If the public's stake and interest warrants large amounts of financial support, why is it then that on paper these entities are still largely only responsible to their "owners" or shareholders? Why do most corporate governance mechanisms, including the remuneration system of executives or the domination of shareholder's versus consumers' interests, reflect a bias, which is so obviously out of tune with what seems to be the economic reality?

In short, the governance of the private corporation is now debated in a context that links it intricately to questions of the wider governance of society and market economies. This special issue of the Journal of Business Ethics addresses some of these recently invigorated questions about the purpose of the firm and how corporations should be governed. The papers in this special issue address six distinct questions some of which have been addressed on-and-off by the scholarly debate for decades but all of which have re-emerged recently as important areas of scholarly debate and the reform of practices with view to more ethical and responsible corporate governance.

\section{Shareholder Supremacy?}

One theme which has emerged in the recent debate on corporate governance in the aftermath of the financial crisis has revolved around rather dated questions about shareholder supremacy. Conspicuously the debate has turned mostly to the question, how it was possible that despite the formal supremacy of shareholders, they have been exposed in so many recent cases to substantial losses. The result is a new attention to questions about the relative priority that should be given to the different stakeholders who have a direct interest in corporate decisions and about the ethical values and principles that should guide prioritization of these interests. Among the most noted voices was former General Electric CEO Jack Welch, a long-standing poster boy of the shareholder value advocates, telling the Financial Times that maximizing shareholder value as a strategy "is a dumb idea" and that "your main constituencies are your employees, your customers and your products" (Guerrera 2009).

On a broader level, the ethical contention would seem to be that in a single minded pursuit of maximizing shareholder value (and performance bonuses) managers have resorted to the exploitation of market imperfections and short term profitability. Arguably this shifts the focus more to the ethical duties of managers in their relationships to all stakeholders, including shareholders, and not simply their duties of maximizing value just for shareholders. It is here that the paper by Joseph Heath makes its contribution. Based on Hansmann's argument in favor of shareholder dominance, Heath argues that this by no means implies that the interests of other stakeholders, most notably employees, can just be ignored. Rather, he argues that the same reasons which justify shareholder supremacy provide the ethical basis for respecting other stakeholders' interest. Shareholder supremacy-as Hansmann argues-is predicated on the fact that this provides the most efficient mechanism of corporate governance. By the same token then, if it is ethical to give shareholders supremacy based on efficiency grounds, so the argument goes, it is equally a "deontic duty" of managers to not undermine market efficiency or exploit market failures in dealing with other stakeholder groups, such as consumers, employees or suppliers-and thereby ignoring potential negative impacts on these constituencies.

The general point for this debate on shareholder supremacy-be it Jack Welch's pragmatic comments or Heath's more theoretical arguments-appears to be that shareholder supremacy in itself relies on ethical presuppositions which are not tantamount to legitimizing ruthless maximization of self-interest by corporations or their managers. In fact it points to a line of inquiry regarding the current state of financial markets where many actors' 
ethical failures appear to consist of contributing to making markets less transparent, less efficient and more prone to moral hazard. Heath would therefore seem to be suggesting that a more enlightened focus on the ethical dimensions of corporate governance may point to a way out of many of the problems the current capitalist system is facing.

\section{Responsible to Whom?}

One example of exploitation of market imperfections in the last years that has been particularly visible is the way in which creditors of companies have been treated. The subprime mortgage crisis has exposed the exploitation of market imperfections with regard to this stakeholder group resulting in significant damage to credit markets in the US and beyond. Similar questions are constantly raised in addressing the ongoing crisis of the Eurozone where "haircuts" (e.g., write offs of liabilities to creditors) seem easy options. The recent case of American Airlines deliberately going into bankruptcy to avoid some of its liabilities to creditors would seem to raise similar issues. Christopher Cowton's paper analyzes the ethical challenges in a firm's relation to creditors by critically examining a number of paradigms which have hitherto governed many companies' approach to this particular stakeholder group.

\section{Board Composition and Responsibilities?}

The debate on the recent failures of corporate governance tends to dedicate considerable attention to addressing the current ethical failures within the current approaches to corporate governance. There is ample ground for arguing that unethical practices within the system rather than the unethical nature of the system itself accounts for many of the undesirable outcomes surfacing after 2008. David Weitzner and Theodoros Peridis' argument can be positioned in this context. It is a strong plea for considering boards in charge not just for some formal, box-ticking exercise at a level largely remote from the day to day business, but to conceptualize the duties of the boards as further reaching. The current ethical duties of boards could be easily extended toward including distinct strategic management responsibilities with regard to issues where business activities have a potential to generate serious harms for individuals and wider society.

\section{Regulation: A Red Flag?}

This said though there is little doubt among experts that part of the problem with contemporary capitalism results from deregulation and weak regulatory oversight. Certainly the Frank-Dodd Act in the US can be seen to point in this direction. Interestingly though, new regulation would seem to be a topic whose discussion has been allocated for the most part to the fields of jurisprudence and law. In contrast, many definitions of business ethics explicitly locate the field in a conceptual space "beyond the law" thus drawing a clear separation between business ethics and legal approaches to address ethical questions. Wayne Norman's paper questions this divide and identifies a broad set of commonalities between both endeavors. Historically, as a small but growing stream of literature has demonstrated (Eberlein and Matten 2009; Moon et al. 2010), a focus on business ethics efforts has resulted in regulative outcomes, be it ex-post by governmental formalization of voluntarily pioneered ethical business practices or ex-ante by voluntary self-regulation by business actors themselves.

\section{Performance for Whom?}

As we have outlined so far, the recently revived interest in corporate governance has ignited rethinking of fairly standard received wisdom on how to run a private business. However, it has also re-ignited debates in more contemporary fields such as CSR. One such area is ongoing debate about the degree to which 'ethics pays' - that is to say the debate on the extent to which corporate social performance impacts financial outcomes for business firms (CSP vs. CFP). Francesco Perrini and co-authors contribute to this debate by categorizing the existing research in this area. Attention to this not exactly new debate seems warranted as stronger demands for more clearly articulated benefits of corporate behavior toward wider society have a crucial influence on the governance of corporations. The relative inconclusiveness of the CSP-CFP debate so far might be considered one of the obstacles to a more deliberate and explicit integration of ethical and social issues in the core corporate governance functions in practice.

\section{Who then are the Stakeholders?}

Times of considerable social change and economic transition tend to lead to new social demands and novel social movements. One current example has certainly been the "Occupy"-protests which became a global phenomenon in just under three months in Fall 2011. The debate on whether or how this might indicate a new set of social demands which business should or should not take seriously is ongoing and controversial which all points to the persistent and newly challenging debate on the changing nature of the relevant stakeholder constituencies for business. Andrew 
Crane and Trish Ruebottom's article contributes to this debate by advancing social identity as a new way of answering the question about who holds legitimate stakes in a firm. Their article can be seen as a reflection of the wider discussion on how societal dynamics impact the understanding of the " $\mathrm{S}$ " in CSR. Most of the stakeholder literature can be interpreted as being transactional in nature, which is to say that the legitimacy of the stakes of traditional groups such as customers, employees, suppliers, competitors, even NGOs, can be predicated on this understanding. A more powerful and conspicuous role of private business, though, exposes business to demands which transcend conventional patterns, and social identity can be considered as one important new way of identifying a company's legitimate stakeholder constituencies.

Acknowledgments The papers resulted from the 2010 Meeting of the Transatlantic Business Ethics Conference (TABEC) held at York University in Toronto, organized by the Canadian Business Ethics Research Network (CBERN). They were subsequently blind reviewed by at least three reviewers in two or more rounds of reviews. We would like to thank the authors for working with us. We also extend our warm thanks to all reviewers for contributing their thoughts to the refinement of the papers published. Reviewers included Kenneth Amaeshi, Alexander Bassen, John Boatright, Krista Bondy, Norman
Bowie, Pat Bradshaw, Leonard Brooks, Sean Buchanan, Itziar Castello, Barry Colbert, Jana Costas, Nathalie Crutzen, Simon Deakin, Aaron Dihr, Yves Fassin, Jean-Pascal Gond, Jared Harris, Wes Helms, Christine Hemingway, Sue Konzelmann, Richard LeBlanc, Chris MacDonald, Richard Nielsen, Brendan O’Dwyer, Sibylle Sachs, Philipp Schreck, David Silver, Grahame Thomspon, Jeffrey Unerman, Patricia Werhane, Andrew Wicks, and Ed Waitzer.

\section{References}

Bakan, J. (2004). The corporation: The pathological pursuit of profit and power. London: Constable and Robinson.

Berle, A. A., \& Means, G. C. (1932). The modern corporation and private property. New York: Transaction.

Crouch, C. (2009). Privatized keynesianism: An unacknowledged policy regime. The British Journal of Politics and International Relations, 11, 382-399.

Eberlein, B., \& Matten, D. (2009). Business responses to climate change regulation in Canada and Germany-lessons for MNCs from emerging economies. Journal of Business Ethics, 86, 241-255.

Guerrera, F. (2009, Mar) Welch denounces corporate obsessions. Financial Times.

Moon, J., Kang, N., Gond, J.-P. (2010). Corporate social responsibility and government. In D. Coen, W. Grant, G. Wilson (Eds.), Oxford handbook of business and government (pp. 512-543). Oxford University Press. 